\title{
PENGGUNAAN FLASHCARD EMOJI DALAM MENINGKATKAN KECERDASAN INTERPERSONAL PADA ANAK TK A SARTIASARI SURABAYA
}

\author{
Eny Ariyanti \\ TK Sartisari, Surabaya \\ Email: blackbutterfly09.bb@gmail.com
}

\begin{abstract}
ABSTRAK
Penelitian ini bertujuan untuk meningkatkan kecerdasan interpersonal anak kelompok A TK Sartiasari Surabaya tahun ajaran 2018-2019 dengan menggunakan pembelajaran flashcard emoji. Penelitian ini merupakan Penelitian Tindakan Kelas (PTK) yang dilakukan dengan dua siklus. Subjek dalam penelitian ini anak kelompok A TK Sartiasari Surabaya dengan usia 4-5 tahun yang berjumlah 28 anak. Objek dalam penelitian ini adalah kecerdasan interpersonal. Teknik pengumpulan data dalam penelitian ini dengan observasi dan dokumentasi. Instrumen penelitian yang digunakan berupa panduan observasi dan di analisis secara deskriptif kuantitatif. Hasil penelitian menunjukkan kemampuan kecerdasan interpersonal anak dapat ditingkatkan melalui pembelajaran flashcard emoji. Anak-anak diajak mengenal ragam ekspresi flashcard emoji, menirukan ragam ekspresi flashcard emoji, mengelompokkan dan menebak ekspresi temannya dengan flashcard emoji. Kemampuan mengenal ragam ekspresi pada pra siklus mencapai 35,6\%, kemudian pada siklus I prosentase rata-rata ketuntasan belajar meningkat menjadi $46,42 \%$ dan prosentase rata-rata ketuntasan belajar pada siklus II meningkat menjadi $85,71 \%$. Peningkatan dari pra siklus ke siklus I sebesar 10,82\%, dan peningkatan dari siklus I ke siklus II sebesar 39,29\%.
\end{abstract}

Kata kunci : kecerdasan interpersonal, flashcard emoji, taman kanak-kanak

\begin{abstract}
This research aims to improve children's interpersonal intelligence group A Kindergarten school year Sartiasari 2018-2019 by using a flashcard learning emoji. This research is a Research Action Class (PTK) conducted two cycles. The subject in this study A group of Kindergaten children Sartiasari Surabaya with age 4-5 years totalling 28 children. The object in this study was interpersonal intelligence. Data collection techniques in the study by observation and documentation. Research instrument used observation and guidance on analysis in quantitative descriptive. The results showed the ability of interpersonal intelligence of children can be improved through learning flashcard emoji. Kids are invited to know the range of expression flashcard emoji, emoji range expressions mimicked the flashcard, classify and guess her friend's expression with a flashcard emoji. The ability to know the range of expression on pre cycle reached $35.6 \%$, then in the cycle I completeness average percentage of learning increased to $46.42 \%$ and the average percentage of completeness study on cycle II increased to $85.71 \%$. Improvement of pre cycle to cycle I of $10.82 \%$, and an increase from cycle I to cycle II amounted to $39.29 \%$.
\end{abstract}

Key words: interpersonal intelligence, flashcard emoji, kindergarten 


\section{PENDAHULUAN}

Masa anak usia dini merupakan periode penting bagi pertumbuhan dan perkembangan anak. Masa ini merupakan masa emas (golden age) dimana anak mengalami pertumbuhan dan perkembangan yang pesat dan merupakan masa yang sensitif untuk menerima berbagai rangsangan dan aktif untuk mengembangkan semua aspek perkembangannya. Masa usia dini juga merupakan peletak dasar untuk mengembangkan kemampuan kognitif, motorik, bahasa, sosial emosional, agama, moral dan kreatifitas.

Salah satu kecerdasan yang penting distimulasi sejak usia dini adalah kecerdasan interpersonal karena dengan bertambahnya usia anak semakin memerlukan cara bersosialisasi dan berinteraksi dengan orang lain. Safaria (2013: 13) menyatakan bahwa anak-anak yang terbatas pergaulan sosialnya akan banyak mengalami hambatan ketika mereka memasuki masa sekolah atau masa dewasa. Anak yang gagal dalam mengembangkan interpersonalnya akan banyak mengalami hambatan pada dunia sosialnya (Safaria, 2005:13). Amstrong (dalam Tadkiroatun, 2010: 7.3) menyatakan bahwa anak dengan kecerdasan interpersonal sangat memperhatikan orang lain, memiliki kepekaan yang tinggi terhadap ekspresi wajah, suara, dan gerak isyarat. Anak dengan kecerdasan interpersonal memiliki banyak kecapakan, kemampuan berempati, kemampuan mengorganisasi, kemamapuan mengenali atau membaca pikiran orang lain, kemampuan berteman dan menjalin kontak.

Berdasarkan hasil observasi di TK A Sartiasari Surabaya, peneliti memperoleh informasi bahwa pada kelompok A kemampuan anak yang berkaitan dengan kecerdasan interpersonalnya masih kurang, dari 28 (100\%) anak ditemukan 18 anak (64,6\%) anak masih belum mampu menunjukkan kecerdasan interpersonal yang ditunjukkan anak masih suka pilih-pilih teman, kurang percaya diri, masih belum sabar saat menunggu giliran, tidak mau berbagi dan masih belum memiliki rasa empati, belum ikut merasakan perasaan orang lain. Hal ini ditunjukkan saat waktu istirahat ada temannya jatuh dan menangis tetapi tidak berusaha untuk menolong atau berusaha untuk memberitahu guru, berebut kursi tidak ada temannya yang mau mengalah ataupun menghiburnya. Beberapa anak tidak memperhatikan penjelasan guru tetapi mengobrol dengan temannya, suka menyendiri saat kegiatan bermain kelompok maupun waktu istirahat. Anak belum bisa mengendalikan diri dengan gampang marah dengan memukul temannya. Sebanyak 10 anak $(35,4 \%)$ anak sudah mampu dalam kecerdasan interpersonal dengan menunjukkan sikap empati, sabar menunggu giliran, mematuhi tata tertib dan aturan pembelajaran, memiliki banyak teman, mau berbagi mainan saat bermain kelompok, mandiri dan percaya diri. Beberapa metode pernah diterapkan di TK A Sartiasari dalam kegiatan-kegiatan pembelajarannya untuk tujuan meningkatkan kecerdasan interpersonal secara optimal pada seluruh peserta didik, diantaranya melalui metode cerita, tanya jawab, bercakap-cakap, dengan kegiatan permainan kelompok, lagu, kegiatan makan bersama, tetapi kecerdasan interpersonal yang diharapkan masih belum tercapai secara optimal. Peneliti memilih untuk menggunakan media flashcard emoji dengan pertimbangan bahwa flashcard emoji merupakan media visual yang menarik perhatian anak dengan tampilan warna warni ragam ekspresi wajah, dapat memberikan situasi belajar yang menyenangkan dengan keterlibatan anak, mudah diingat dan dimaknai oleh anak.

Dalam kegiatan pembelajaran flashcard emoji anak-anak dapat terlibat aktif dengan melihat ragam ekspresi flashcard emoji dengan ragam gambar ekspresi wajah senang, gembira, sedih, menangis, takut, marah. Penggunaan flashcard emoji bertujuan untuk 
meningkatkan kecerdasan interpersonal dengan melatih agar anak mulai mengenal ragam ekspresi wajah, menirukannya, dapat menyampaikan maknanya, dan menerapkannya dalam bentuk perilaku. Bermain flashcard emoji secara tidak langsung anak dirangsang memiliki kepekaan terhadap orang lain, maksud, tujuan, kesabaran, kedisiplinan dan kemandirian. Sebagai media pembelajaran flashcard emoji disesuaikan kondisi dan tujuan dari kegiatan pembelajaran yang ingin dicapai, maka perlu dilakukan adanya penelitian dalam upaya meningkatkan kecerdasan interpersonal anak.

Sesuai dengan latar belakang masalah diatas, peneliti melakukan penelitian dengan metode penelitian tindakan kelas dengan memfokuskan pada upaya guru dalam meningkatkan kecerdasan interpersonal. Untuk itu penelitian ini diberi judul "Penggunaan Flashcard Emoji Dalam Meningkatkan Kecerdasan Interpersonal Pada Anak TK A Sartiasari Surabaya".

\section{METODE PENELITIAN}

Penelitian ini menggunakan Penelitian Tindakan Kelas (PTK) sebagai upaya peneliti meningkatkan pembelajaran di dalam kelas dengan media flasdcard emoji untuk memperbaiki praktek pembelajaran yang sudah ada. Penelitian tindakan kelas pertama dikemukakan oleh Kurt Lewin pada tahun 1946 yang kemudian dikembangkan oleh Stephen Kemmis dan Mc.Taggart dan John Elliot. Menurut Kemmis dan Mc. Taggart (dalam Sukardi, 2013: 3) menyatakan penelitian tindakan kelas adalah cara suatu kelompok atau seseorang dalam mengorganisasi sebuah kondisi dimana mereka dapat mempelajari pengalaman dan membuat pengalaman mereka dapat diakses orang lain. Penelitian Tindakan Kelas dilaksanakan sebagai upaya untuk meningkatkan kualitas pendidikan terutama proses dan hasil belajar pada kelas.

Penelitian tindakan kelas digambarkan dengan siklus yang dilaksanakan tiga kali pertemuan dengan model dan penjelasan untuk masing-masing tahap. Tahapan-tahapan tersebut tergambar dalam pola sebagai berikut :

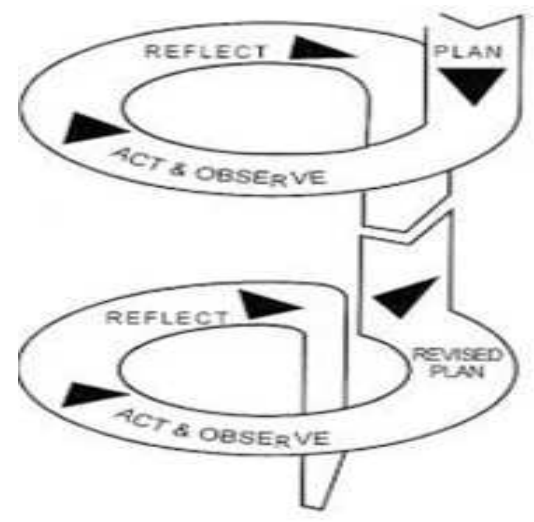

Gambar 1. Model Spiral PTK Kemmis \& Taggart

(dalam Kusumah dan Dwitagama, 2009:20)

Lokasi penelitian tindakan kelas dilakukan di TK Sartiasari Surabaya, dengan penelitian dilaksanakan pada anak kelompok A. Peneliti memilih TK Sartiasari. Penelitian dilakukan pada semester genap tahun ajaran 2018-2019 pada bulan April sampai dengan bulan Juni 2019 dengan perincian waktu satu bulan pertama pengamatan dan observasi sebelum tindakan. Penelitian satu bulan kedua dilakukan dengan penyusunan rencana 
kegiatan siklus I dan II dilanjutkan dengan tindakan penelitian, satu bulan ketiga pengolahan data dan penyusunan hasil penelitian. Subjek penelitian adalah siswa kelompok A TK Sartiasari Surabaya Tahun Ajaran 2018-2019 dengan jumlah 15 anak lakilaki dan 13 anak perempuan dengan usia anak 4-5 tahun. Objek penelitian adalah kecerdasan interpersonal anak.

Dalam penelitian tindakan kelas (PTK) ada empat tahapan yang harus dilakukan dalam penelitian yang dilakukan secara berulang-ulang sampai pada tercapainya hasil yang diinginkan. Menurut Arikunto (2007:16) empat langkah yang harus dilakukan dalam tahap-tahap penelitian tindakan kelas (PTK) antar lain: a) perencanaan (planning), b) pelaksanaan (acting), c) pengamatan (observating), d) refleksi (reflecting). Penelitian dilakukan dengan menggunakan siklus dengan setiap siklus ada empat langkah yang harus dilakukan dan diulang-ulang sampai tercapainya hasil yang sudah ditetapkan. Di sini dapat dijelaskan bahwa dalam siklus pertama belum didapatkan peningkatan maka akan diulang pada siklus kedua dan seterusnya sampai tercapainya hasil yang telah ditetapkan.

\section{Teknik dan Instrumen Pengumpulan Data}

Teknik pengumpulan data sangat penting dilakukan karena pemerolehan data dalam sebuah penelitian akan dijadikan sebagai bahan dan sebagai bukti untuk dijadikan penelitian. Menurut Arikunto (2006: 150-158) menyebutkan bahwa jenis metode pengumpulan data terdiri dari tes, angket, interview, observasi, skala bertingkat dan dokumentasi. Dalam penelitian ini peneliti menggunakan teknik pengumpulan data sebagai berikut :

\section{Observasi}

Observasi dilakukan dengan cara mengamati kemampuan anak dalam mengenal ragam ekspresi yang sesuai dengan indikator penilaian yaitu kemampuan menunjukkan sikap toleransi, menunjukkan rasa empati, menghargai orang lain, menghargai keunggulan orang lain, mengekspresikan perasaan, memahami peraturan dan kedisiplinan. Observasi dilakukan saat proses berlangsungnya pembelajaran, saat anak istirahat diluar kelas, saat anak datang dan sampai anak pulang sekolah.

Tabel 1. Lembar Observasi Anak TK A Sartiasari Surabaya

\begin{tabular}{|c|c|c|c|c|c|c|c|c|c|c|c|c|c|c|c|c|c|c|}
\hline \multirow[t]{3}{*}{ No } & \multirow{3}{*}{$\begin{array}{l}\text { Nama } \\
\text { Anak }\end{array}$} & \multicolumn{16}{|c|}{ Aspek Yang Diamati } & \multirow{3}{*}{$\begin{array}{l}\text { Total } \\
\text { Skor }\end{array}$} \\
\hline & & \multicolumn{4}{|c|}{$\begin{array}{c}\text { Menyebutkan } \\
\text { ragam } \\
\text { ekspresi } \\
\text { flashcard } \\
\text { emoji } \\
\end{array}$} & \multicolumn{4}{|c|}{$\begin{array}{l}\text { Menirukan } \\
\text { ragam } \\
\text { ekspresi } \\
\text { flashcard } \\
\text { emoji } \\
\end{array}$} & \multicolumn{4}{|c|}{$\begin{array}{c}\text { Mengelom- } \\
\text { pokkan ragam } \\
\text { ekspresi yang } \\
\text { baik dan tidak } \\
\text { baik }\end{array}$} & \multicolumn{4}{|c|}{$\begin{array}{c}\text { Memahami } \\
\text { ekspresi orang } \\
\text { lain }\end{array}$} & \\
\hline & & 1 & 2 & 3 & 4 & 1 & 2 & 3 & 4 & 1 & 2 & 3 & 4 & 1 & 2 & 3 & 4 & \\
\hline \multicolumn{19}{|l|}{1.} \\
\hline 2. & & & & & & & & & & & & & & & & & & \\
\hline \multicolumn{19}{|c|}{ Jumlah } \\
\hline Rat & rata & & & & & & & & & & & & & & & & & \\
\hline
\end{tabular}

Kriteria penilaian :

1. Belum berkembang $(\mathrm{BB})$

2. Mulai berkembang (MB) 
3. Berkembang sesuai harapan (BSH)

4. Berkembang sangat baik (BSB)

Tabel 2. Rubrik penilaian :

\begin{tabular}{|c|c|c|}
\hline Aspek yang diamati & Skor & Kriteria penilaian \\
\hline \multirow[t]{4}{*}{$\begin{array}{l}\text { Anak menyebutkan ragam } \\
\text { ekspresi flashcard emoji }\end{array}$} & 4 & $\begin{array}{l}\text { Anak mampu menyebutkan } 6 \text { ekspresi } \\
\text { flashcard emoji yang ditunjukkan guru }\end{array}$ \\
\hline & 3 & $\begin{array}{l}\text { Anak mampu menyebutkan } 4 \text { ekspresi } \\
\text { flashcard emoji yang ditunjukkan guru }\end{array}$ \\
\hline & 2 & $\begin{array}{l}\text { Anak mampu menyebutkan } 2 \text { ekspresi } \\
\text { flashcard emoji yang ditunjukkan guru }\end{array}$ \\
\hline & 1 & $\begin{array}{l}\text { Anak belum bisa menyebutkan ragam ekspresi } \\
\text { dari flashcard emoji yang ditunjukkan guru }\end{array}$ \\
\hline \multirow[t]{4}{*}{$\begin{array}{l}\text { Anak menirukan ragam } \\
\text { ekspresi flashcard emoji }\end{array}$} & 4 & $\begin{array}{l}\text { Anak mampu menirukan } 6 \text { ekspresi flashcard } \\
\text { emoji yang ditunjukkan guru }\end{array}$ \\
\hline & 3 & $\begin{array}{l}\text { Anak mampu menirukan } 4 \text { ekspresi flashcard } \\
\text { emoji yang ditunjukkan guru }\end{array}$ \\
\hline & 2 & $\begin{array}{l}\text { Anak mampu menirukan } 2 \text { ekspresi flashcard } \\
\text { emoji yang ditunjukkan guru }\end{array}$ \\
\hline & 1 & $\begin{array}{l}\text { Anak belum mampu menirukan ragam ekspresi } \\
\text { flashcard emoji yang ditunjukkan guru }\end{array}$ \\
\hline \multirow{4}{*}{$\begin{array}{l}\text { Anak mengelompokkan } \\
\text { flashcard emoji yang baik } \\
\text { dan ekspresi buruk }\end{array}$} & 4 & $\begin{array}{l}\text { Anak mampu mengelompokkan } 6 \text { ekspresi } \\
\text { flashcard emoji }\end{array}$ \\
\hline & 3 & $\begin{array}{l}\text { Anak mampu mengelompokkan } 4 \text { ekspresi } \\
\text { flashcard emoji }\end{array}$ \\
\hline & 2 & $\begin{array}{l}\text { Anak mampu mengelompokkan } 2 \text { ekspresi } \\
\text { flashcard emoji }\end{array}$ \\
\hline & 1 & $\begin{array}{l}\text { Anak belum mampu mengelompokkan ragam } \\
\text { ekspresi flashcard emoji }\end{array}$ \\
\hline \multirow[t]{4}{*}{$\begin{array}{l}\text { Anak memahami ekspresi } \\
\text { orang lain }\end{array}$} & 4 & $\begin{array}{l}\text { Anak mampu memahami } 6 \text { ekspresi yang } \\
\text { diperagakan temannya }\end{array}$ \\
\hline & 3 & $\begin{array}{l}\text { Anak mampu memahami } 4 \text { ekspresi yang } \\
\text { diperagakan temannya }\end{array}$ \\
\hline & 2 & $\begin{array}{l}\text { Anak mampu memahami } 2 \text { ekspresi yang } \\
\text { diperagakan temannya }\end{array}$ \\
\hline & 1 & $\begin{array}{l}\text { Anak belum mampu memahami ragam } \\
\text { ekspresi yang diperagakan temannya }\end{array}$ \\
\hline
\end{tabular}

\section{Dokumentasi}

Dokumentasi digunakan untuk melengkapi dan menguatkan data-data yang sudah diperoleh mengenai kemampuan anak dalam kecerdasan interpersonal yang berupa catatan harian, lembar observasi , data buku perkembangan anak dan foto-foto kegiatan. Menurut Sugiyono (2008: 29) dokumentasi merupakan catatan yang sudah berlalu, bisa berbentuk tulisan, gambar atau karya-karya seseorang.

\section{Instrumen Penelitian}

Instrumen observasi penelitian tindakan kelas ini memuat indikator keberhasilan tingkat capaian perkembangan pada bidang pengembangan kemampuan anak sebagaimana yang diharapkan, sehingga dapat menggambarkan keberhasilan dan kekurangan 
keseluruhan tindakan dalam upaya peningkatan kecerdasan interpersonal anak kelompok A TK Sartiasari Surabaya melalui penerapan flashcard emoji dalam pembelajaran. Instrumen pengamatan berguna sebagai acuan untuk menentukan kriteria setiap indikator materi pengamatan dalam rangka mengevaluasi aktivitas anak dalam proses pembelajaran sebagai bahan refleksi guru.

\section{Teknik Analisis Data}

\section{Analisis Data Hasil Ketuntasan Belajar}

Penelitian ini menggunakan teknik analisis deskriptif kuantitatif yang digunakan untuk menjelaskan dengan kata-kata semua kesimpulan hasil penelitian. Semua data yang berupa angka-angka yang diperoleh akan dianalisis terlebih dahulu menggunakan rumus statistik sederhana. Komposisi anak dianalisis tingkat antusias dan tingkat pemahaman. Kemudian, mereka diberi tingkat penguasaan untuk mengetahui bagaimana tingkat antusias dan tingkat pemahaman macam-macam ekspresi dan arti flashcard emoji. Kriteria tingkat penguasaan untuk antusias dan tingkat pemahaman diciptakan oleh peneliti. Analisis dari data dari hasil observasi terhadap kemampuan kecerdasan interpersonal yang diadaptasi dari Sudijono (2009:43)

$$
\mathrm{P}=\frac{f}{N} x 100 \%
$$

Keterangan :

$\mathbf{P}=$ Prosentase frekuensi kejadian yang muncul

$\mathbf{f}=$ Frekuensi atau banyaknya aktivitas anak yang muncul

$\mathbf{N}=$ Jumlah aktivitas keseluruhan

\section{Kriteria Keberhasilan}

Anak dinyatakan berkembang sangat baik adalah yang mendapatkan skor 4, anak yang berkembang sesuai harapan mendapat skor 3, sedangkan anak yang dinyatakan mulai berkembang mendapat skor 2 dan anak yang dinyatakan belum mampu berkembang mendapat skor 1 . Penelitian dinyatakan berhasil apabila $80 \%$ dari jumlah anak mendapat minimal skor 3 dengan kriteria berkembang sesuai harapan.

\section{HASIL PENELITIAN DAN PEMBAHASAN}

\section{Hasil Observasi Pra Tindakan}

Sebelum melakukan penelitian, peneliti melakukan pengamatan untuk mengetahui kondisi awal kemampuan interpersonal anak TK A Sartiasari Surabaya. Kegiatan pra tindakan dilakukan pada tanggal 29 April 2019. Dari hasil pra tindakan yang dilakukan terhadap 28 anak dengan menggunakan instrumen skor penilaian menunjukkan sebanyak 18 anak $(64,6 \%)$ masih belum mampu menunjukan kecerdasan interpersonal dan hanya 10 anak $(35,4 \%)$ yang sudah mampu dalam kecerdasan interpersonalnya. Dari hasil pengamatan tersebut peneliti menemukan beberapa permasalahan yang kemudian dijadikan sebagai bahan refleksi untuk menentukan perencanaan dalam pembelajaran siklus I, yang 
antara lain perlu adanya peningkatan kualitas aktivitas guru dan peningkatan aktivitas anak. Penyampain materi harus lebih detail dan suara guru dapat didengar jelas oleh seluruh anak. Guru mengkondisikan anak siap menerima pembelajaran dan anak dalam kondisi siap menerima pembelajaran dari guru.

\section{Hasil Penelitian}

Langkah selanjutnya peneliti melakukan tindakan pada siklus I dan siklus II untuk meningkatkan kemampuan kecerdasan interpersonal anak dengan pembelajaran flashcard emoji. Tabel penilaian tingkat capaian perkembangan anak yang digunakan pada masing masing siklus adalah sebagai berikut :

Tabel 3. Hasil Tingkat Capaian Perkembangan Kemampuan Kecerdasan Interpersonal Pada Anak Kelompok A TK Sartiasari Surabaya Melalui Pembelajaran Flashcard Emoji (Pertemuan I)

\begin{tabular}{|c|c|c|c|c|c|c|c|c|c|c|c|c|}
\hline \multirow[t]{2}{*}{ No. } & \multirow[t]{2}{*}{ Nama } & \multicolumn{4}{|c|}{$\begin{array}{l}\text { Menyebut-kan } \\
\text { ragam ekspresi } \\
\text { flashcard emoji }\end{array}$} & \multicolumn{4}{|c|}{$\begin{array}{l}\text { Menirukan } \\
\text { ragam ekspresi } \\
\text { flashcard emoji }\end{array}$} & \multirow[t]{2}{*}{ Total } & \multirow[t]{2}{*}{$\%$} & \multirow[t]{2}{*}{ Ket } \\
\hline & & 1 & 2 & 3 & 4 & 1 & 2 & 3 & 4 & & & \\
\hline \multicolumn{13}{|l|}{1.} \\
\hline \multicolumn{13}{|l|}{2.} \\
\hline \multicolumn{13}{|c|}{ Jumlah } \\
\hline \multicolumn{10}{|c|}{ Rata-rata Kelas } & & & \\
\hline
\end{tabular}

Tabel 4. Hasil Tingkat Capaian perkembangan Kemampuan Kecerdasan Interpersonal Pada Anak Kelompok A TK Sartiasari Surabaya Melalui Pembelajaran Flashcard Emoji (Pertemuan II)

\begin{tabular}{|c|c|c|c|c|c|c|c|c|c|c|c|c|}
\hline \multirow[t]{2}{*}{ No. } & \multirow[t]{2}{*}{ Nama } & \multicolumn{4}{|c|}{$\begin{array}{c}\text { Mengelom- } \\
\text { pokkan } \\
\text { flashcard emoji } \\
\text { ekspresi baik } \\
\text { dan ekspresi } \\
\text { buruk } \\
\end{array}$} & \multicolumn{4}{|c|}{$\begin{array}{l}\text { Memahami } \\
\text { ekspresi orang } \\
\text { lain dengan } \\
\text { mengambil } \\
\text { flashcard emoji } \\
\text { yang sesuai }\end{array}$} & \multirow[t]{2}{*}{ Total } & \multirow[t]{2}{*}{$\%$} & \multirow[t]{2}{*}{ Ket } \\
\hline & & 1 & 2 & 3 & 4 & 1 & 2 & 3 & 4 & & & \\
\hline \multicolumn{13}{|l|}{1.} \\
\hline \multicolumn{13}{|c|}{2.} \\
\hline \multicolumn{13}{|c|}{ Jumlah } \\
\hline Rat & ata Ke & & & & & & & & & & & \\
\hline
\end{tabular}

\section{Siklus I}

Tindakan siklus I dilakukan dua kali pertemuan. Dalam pertemuan ini peneliti melakukan pengamatan dan penilaian terhadap tingkat pencapain kecerdasan interpersonal anak. Berdasarkan data diatas diperoleh hasil pada siklus I pertemuan I dari 28 anak didapatkan nilai rata-rata kelas $62,5 \%$. Anak yang mencapai ketuntasan belajar berjumlah 8 anak dengan prosentase ketuntasan belajar sebesar 28,6\%. Pada siklus I pertemuan II dari 28 anak yang mempunyai kemampuan membedakan ekspresi baik buruk, mengelompokkan dan memahami ekspresi ternyata masih rendah, didapatkan nilai ratarata kelas sebesar $68,75 \%$ dengan jumalah anak yang mencapai ketuntasan belajar sebanyak 13 anak dengan prosentase ketuntasan belajar sebesar 46,42\%. 


\section{Siklus II}

Tindakan pada siklus II dilakukan dua kali pertemuan. Dengan melihat hasil tindakan dari siklus II dapat disimpulkan tingkat capaian perkembangan kemampuan kecerdasan interpersonal anak terjadi peningkatan. Dari data siklus II pertemuan pertama dari jumlah 28 anak didapatkan nilai rata-rata kelas sebesar 75,89\% dengan jumlah anak yang mencapai ketuntasan belajar sebanyak 21 anak dengan prosentase ketuntasan belajar sebesar $75 \%$.

Pada siklus II pertemuan kedua dari 28 aank diperoleh data nilai rata-rat kelas sebesar $85,71 \%$ dengan jumlah anak yang mencapai ketuntasan belajar sebesar 24 anak dengan nilai ketuntasan belajar sebesar $85,71 \%$. Nilai rata-rata tersebut sudah menunjukkan peningkatan sebesar $16,96 \%$ dibandingkan dengan nilai rata-rata pada siklus I. Dengan demikian membuktikan bahwa pembelajaran dengan media flashcard emoji dapat meningkatkan hasil belajar dalam usaha meningkatkan kecerdasan interpersonal dari siklus I ke siklus II.

Berdasarkan perolehan prosentase dari kegiatan yang telah dilakukan pada siklus II pertemuan I dan II dapat dikatakan berhasil dengan diketahui bahwa dari 28 anak nilai rata-rata kelas didapatkan $85,71 \%$. Jumlah anak yang mencapai ketuntasan belajar berjumlah 24 anak dengan prosentase ketuntasan sebesar 85,71\%. Hasil dari pembelajaran pada siklus II pertemuan I dan II dapat diketahui jumlah nilai semua anak adalah 2.393. Jumlah hasil belajar semua anak dibagi dengan banyak anak (28 anak) sehingga diperoleh rata-rata kelas sebesar $85,71 \%$. Nilai raat-rata tersebut sudah menunjukkan peningkatan sebesar 15,18 dibandingkan dengan nilai rata-rata pada siklus I. Dengan demikian membuktikan bahwa pembelajaran dengan media flashcard emoji dapat meningkatkan hasil belajar dalam upaya peningkatan kecerdasan interpersonal dari siklus I ke siklus II.

\section{PEMBAHASAN}

Dalam penelitian tindakan kelas ini telah dilakukan secara bertahap pada kegiatan siklus I meningkatkan kecerdasan interpersonal melalui media flashcard emoji sebesar 46\% sehingga perencanaan tindakan pada siklus II berdasarkan dari masalah-masalah yang menghambat perkembangan kecerdasan interpersonal melalui permainan flascard emoji pada kelompok A TK Sartiasari Surabaya.

Setelah diadakan perbaikan pembelajaran dengan langkah-langkah tindakan aktivitas mengajar yang dilakukan guru mempunyai pengaruh yang tinggi pada siklus II yang mana meningkat menjadi $85,71 \%$. Hasil akhir dari siklus II telah menunjukkan peningkatan kemampuan kecerdasan interpersonal, sehingga penelitian tindakan kelas ini dinyatakan berhasil.

Prosentase peningkatan siklus II menunjukkan adanya perubahan yang signifikan pada perkembangan kecerdasan interpersonal anak. Dalam pelaksanaan kegiatan pembelajaran dengan media flashcard emoji respon anak sangat antusias, anak-anak terlibat langsung sehingga aktifitas pengenalan ragam ekspresi untuk peningkatan kecerdasan interpersonal anak dapat tercapai dengan optimal, yang mana sesuai dengan pendapat Hamalik (1986:12) yang mengemukakan bahwa dengan memanfaatkan media pembelajaran atau alat peraga dalam proses pembelajaran dapat membangkitkan keinginan dan minat yang baru, dan dapat memotivasi belajar anak, serta membawa pengaruhpengaruh psikologis terhadap anak. Flashcard emoji merupakan alat peraga yang dapat 
digunakan pendidik sebagai alat bantu dalam mengajarkan ragam ekspresi dalam upaya peningkatan kecerdasan interpersonal anak didik.

Pada pelaksanaan setiap siklus dapat menambah banyak pemahaman ragam ekspresi sehingga anak dapat mengembangkan kemampuan kecerdasan interpersonalnya melalui permainan flashcard emoji disetiap siklusnya. Berdasarkan hasil penelitian ini dapat terbukti

bahwa melalui media flashcard emoji anak merasa tertarik dalam mengembangkan kecerdasan interpersonalnya. Hasil analisis pada siklus II juga membedakan efektifitas pembelajaran berdasarkan skor nilai kemampuan kecerdasan interpersonal anak. Hal ini juga menunjukkan perbedaan yang signifikan dari tahap-tahap tindakan kelas dalam siklus pembelajarn yang dilakukan. Dengan permainan flashcard emoji untuk mengenalkan ragam ekspresi pada anak kelompok A TK Sartiasari Surabaya diharapkan minat belajar anak meningkat sehingga berpengaruh pada perkembangan kemampuan kecerdasan interpersonal anak.

Berikut rekapitulasi data aktifitas anak dalam kemampuan belajar :

\section{Gambar 5. Grafik Rekapitulasi Data Aktifitas Anak Dalam Kemampuan Belajar}

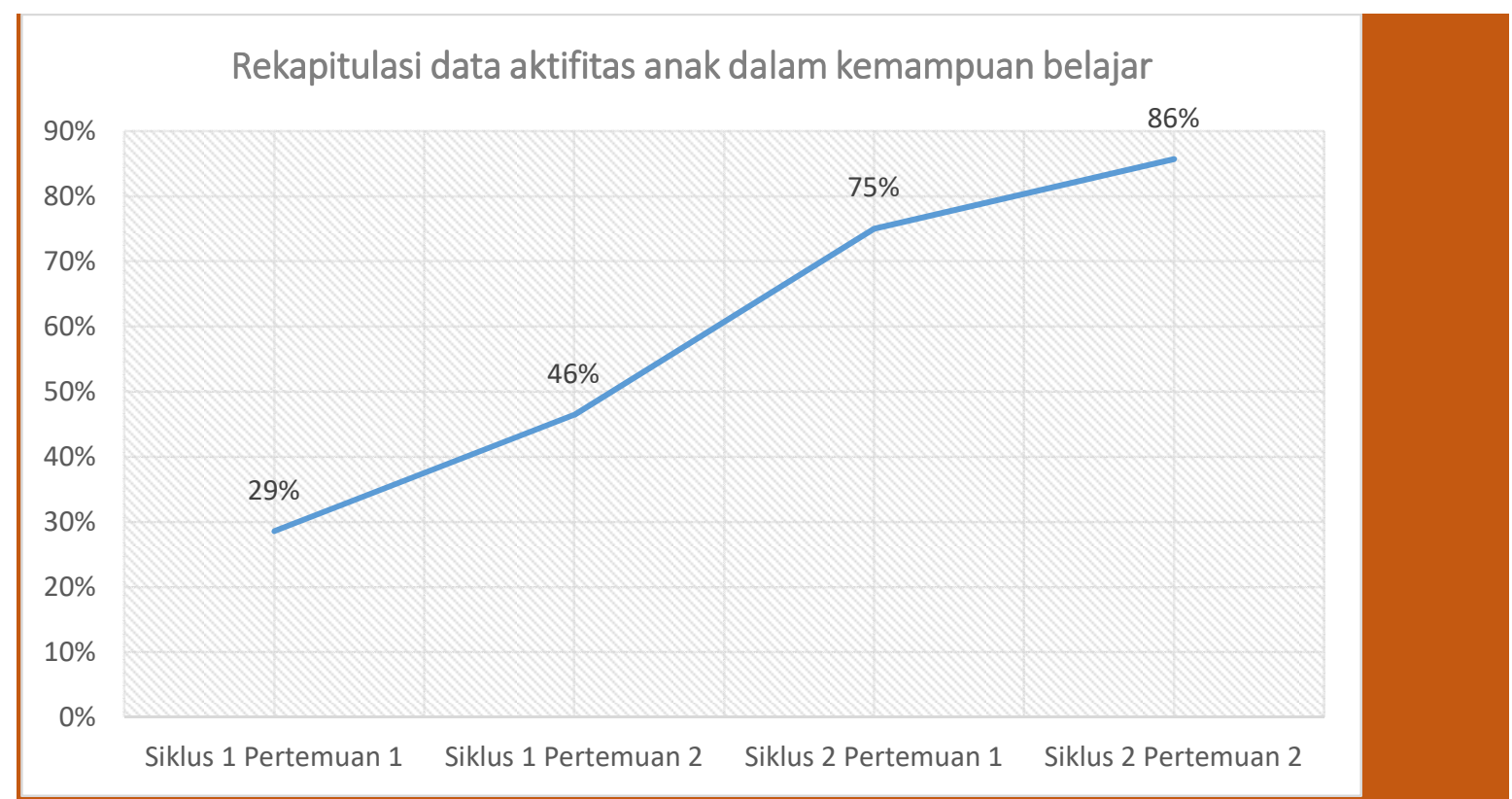

Setelah dipaparkan hasil dari siklus I ke siklus II serta dengan melihat peningkatan skor melalui grafik diatas dapat dinyatakan bahwa penelitian ini membuktikan bahwa media flashcard emoji dapat membantu meningkatkan kemampuan kecerdasan interpersonal anak.

\section{PENUTUP}

\section{Kesimpulan}

Berdasarkan hasil penelitian dan pembahasan pada bab IV dapat disimpulkan bahwa melalui kegiatan pembelajaran dengan media flashcard emoji dapat meningkatkan kemampuan kecerdasan interpersonal pada kelompok A TK Sartiasari Surabaya. Hal ini dapat diketahui dari hasil tingkat capaian perkembangan anak mencapai $85,71 \%$ pada pembelajaran siklus II pertemuan II. 
Dengan permainan flashcard emoji pada anak kelompok A TK Sartiasari Surabaya dapat merangsang anak untuk berfikir sekaligus memperoleh pengalaman baru tentang pemahaman dan pengertian sesuatu dengan menggunakan benda atau peristiwa konkret.

\section{Saran}

1. Bagi satuan PAUD

Untuk satuan pendidikan anak usia dini dapat menggunakan permainan flashcard emoji untuk meningkatkan kemampuan kecerdasan interpersonal anak kelompok A.

2. Bagi Peneliti Lain

a. Penelitian ini dapat dijadikan sebagai bahan referensi bagi peneliti berikutnya khususnya pada kegiatan pembelajaran pengenalan ragam ekpresi dalam kemampuan kecerdasan interpersonal dengan menggunakan permainan yang menarik.

b. Dengan fokus pada subyek penelitian di kelompok A TK Sartiasari Surabaya diharapkan dapat diperluas dengan subyek yang lebih besar dan latar belakang serta permasalahan yang berbeda.

\section{DAFTAR PUSTAKA}

Arikunto, Suharsimi. 2007. Manajemen penelitian. Jakarta: Rineka Cipta

Armstrong, Thomas. 2002. Setiap Anak Cerdas : Panduan Membantu Anak Belajar Dengan Memanfaatkan Multiple Intelligence-nya. Jakarta: Gramedia Pustaka Utama.

Armstrong, Thomas. 2003. Sekolah Para Juara. Bandung: Kaifa.

Safaria, T. Interpersonal Intelligence: Metode Pengembangan Kecerdasan Interpersonal Anak, (Yogyakarta: Amara Books, 2005), Hlm. 19

Sukardi. 2011. Metodologi Penelitian Pendidikan. Jakarta: Bumi Aksara Thomas, Amstrong, Setiap Anak Cerdas, hlm. 88.

Sukardi. 2013. Metode Penelitian Pendidikan Tindakan Kelas : Implemntasi dan Pengembangannya. Jakarta: PT Bumi Aksara.

Wijaya Kusumah \& Dedi Dwitagama. 2011. Mengenal Penelitian Tindakan Kelas. Jakarta: Indeks. 